Review Article

\title{
Review on Ethnomedicinal and Pharmacological Uses of Echinops kebericho Mesfin in Ethiopia
}

\section{Gadisa Demie}

Forestry Department, College of Agriculture and Veterinary Science, Ambo University, Ambo, Ethiopia

Email address:

gadisademie@gmail.com

\section{To cite this article:}

Gadisa Demie. Review on Ethnomedicinal and Pharmacological Uses of Echinops kebericho Mesfin in Ethiopia. Journal of Diseases and Medicinal Plants. Vol. 5, No. 5, 2019, pp. 78-86. doi: 10.11648/j.jdmp.20190505.12

Received: September 4, 2019; Accepted: October 29, 2019; Published: November 13, 2019

\begin{abstract}
The genus Echinops is native to African countries, the Middle East, Europe, and Asia comprises 120 species. In Ethiopia, this genus is represented by well known endemic and critically endangered species Echinops kebericho Mesfin also known as "Kebercho," in Amharic language which has a long history of ethnomedicinal uses. Due to the popularity of species as a source of ethnomedicine, this species is severely over-harvested throughout their distributional ranges. This review documents fragmented information on traditional uses and pharmacological evidence of Echinops kebericho in Ethiopia. This review article was carried out by searching studies in PubMed, Google scholar and Google search up to August 2019. The search terms were "Echinops kebericho Mesfin", "therapeutic" \& "pharmacological". Ethnomedicinal uses of Echinops kebericho Mesfin has been recorded from different regions of Ethiopia for 32 human and 2 livestock ailments. E. kebericho is used to treat evil eye, headache, cough, stomachache, febrile illness and malaria ailments. The extracts of E. kebericho, particularly those from root, exhibited a wide range of pharmacological effects including antihelminthic, antibacterial, antifungal, antidiarrheal, anti spasmolytic and antimalarial activities. These pharmacological studies have established a scientific basis for therapeutic uses of Echinops kebericho Mesfin. Although Ethiopian Echinops kebericho is widely used by traditional practitioners but, it is threatened due to over exploitation of root part. Therefore, E. kebericho need urgent conservation attention, micro propagation, effective documentation and further research.
\end{abstract}

Keywords: Echinops kebericho Mesfin, Ethnomedicinal, Pharmacology

\section{Introduction}

The uses of medicinal plants have been widely practiced for thousands of years to treat various diseases in all over the world [1]. More than 35,000 plant species are being used as traditional medicine around the world [2]. In developing countries, about $80 \%$ of population still relies on traditional medicine for their primary health care [3]. The African countries also have a long history and up to $90 \%$ of the human population use medicinal plants as a source of drugs [4]. Likewise, traditional medicine has played a significant role in treating various ailments in Ethiopia [5-7]. The current reports revealed that around $80 \%$ of Ethiopian human population still depends on medicinal plants to fulfill their primary healthcare requirements [6], largely due to its cultural acceptability of healers, relatively low cost of traditional medicine [8], and lack of adequate healthcare services suffering the larger population of the country [9]. Nowadays, medicinal plants are not only used as local and traditional aliment but also registered as official remedy that is confirmed with pharmacopoeias [10]. Furthermore, a photochemical screening, often leads to the discovery of new compounds that can play a significant role in the global efforts against various ailments [11]. More than $50 \%$ of all modern drugs have natural origin; therefore, these products have a great role in the pharmaceutical sciences for drug development [12]. The current investigations have indicated that around $25 \%$ of the modern remedies have been obtained from medicinal plants [13].

Echinops kebericho Mesfin is also a plant with immense medicinal values with restricted distribution in Ethiopia. It is an erect enormous root stock-bearing perennial herb or shrub 
that grows up to a height of $1.2 \mathrm{~m}$ with leafy stems [14]. It is a well known endemic and critically endangered medicinal plant belonging to family Asteraceae. Echinops kebericho has been used for curative and therapeutic properties intreating various infectious and non infectious diseases such as fever, headache, stomachache, malaria, and cough [15]. In the pharmacological action E.keberichoroot extracts have also been reported forantihelmintic, antitumor, antimutagenic, antibacterial and fungicidal properties [16, 17]. In addition, extracts and essential oils of the roots were shown to have antimicrobial, antihelminthic, molluscicidal and in vivo antiplasmodialactivities $[15,18]$. Current investigation has identified that E. kebericho have been reported to control veterinary and agricultural insect pests [19]. Because of their versatile biological and therapeutic activities, E. kebericho plants have been traditionally used for the treatment of various diseases in different parts of Ethiopia. However, there has not been any review conducted on therapeutic and pharmacological uses of Echinops kebericho to treat various diseases. Therefore, the present review compiles the fragmented information on the traditional and pharmacology uses of the Echinops kebericho species. This information will highlight the importance of the genus and will provide baseline information for future researchers intending to do further work on genus Echinops.

\section{Material and Methods}

A systematic analysis and review of research literatures related to genus Echinops used for traditional diseases treatment in Ethiopia was carried out between Januarys and August, 2019. A web-based systematic research literature search strategy was employed. Ethno-botanical/ethno-medicinal studies reporting on Echinops kebericho used for diseases treatment in Ethiopia were gathered by different search approaches, including; search for published journal articles using international scientific databases including PubMed, Google search, Google scholar, etc. Literature search was performed using the following key terms: Ethiopian Echinops kebericho/Traditional medicinal use Echinops kebericho plant, Ethnobotany/Ethnobotanical study of Echinops kebericho and Ethnopharmacology of genus Echinops in Ethiopia. All data were entered into Statistical Software Packages for Social Science (SPSS, software version 20). A descriptive statistical methods, percentage and frequency were used to analyze ethno-botanical data on reported Echinops kebericho plant. The results were presented using tables.

\section{Results}

The present review reported the majority of studies were in Oromia region located in the central part of Ethiopia. In most of the reported studies, the majority of informants were men (traditional healers, laypeople and experienced elders) at the ages between 35 and 85 years. In almost all studies, number of informants or interviewees was above 30. Mostly, field surveys, group discussions, and semi structured questionnaires were carried out from local inhabitants to collect the data. However, in some of the studies, direct interviews were also observed. A brief overview of the results is presented in the following sections.

\subsection{Botanical Features and Distribution of Echinops Kebericho Mesfin}

In Ethiopia, E. kebericho known by common name "Kebercho" in Amharic language [20, 21]. Echinops kebericho Mesfin belongs to the Asteraceae family, known only in Ethiopia, is an erect massive root stock-bearing perennial herb or shrub that grows up to a height of $1.2 \mathrm{~m}$ with leafy stems [22]. The leaf lamina is curved and is detached into pieces that consistently end in spikes. The corolla is white or brilliant blue [23]. Flower head 3-4 in diameter, spineless peduncle up to $5.5 \mathrm{~cm}$ long, arachnoid, pubscent, $1-2 \mathrm{~mm}$ wide. Echinops kebericho, is endemic and critically endangered medicinal plant in Ethiopia.

Literatures reviews revealed that, 38 studies focused on genus Echinops, were found to be therapeutically evaluated. Among the genus Echinops known for medicinal value in Ethiopia, more than half $(63 \%)$ of the genusbelonging to family Asteraceae (Echinops kebericho Mesfin) was confirmed for its therapeutic potentials. Echinops kebericho Mesfin, Echinops maracandicus Bunge, Echinops hispidus Fresen, Echinops pappii Chiov, Echidnopsis dammanniana Sprenger, Echinops amplexicaulis Oliv, Echinops cacrochaetus and Echinops giganteus A. Richare examples ofknown species of genus Echinops which grow in different parts of Ethiopia and are known to have medicinal properties [24-30]. The majority of Echinops kebericho Mesfin uses reported in Oromia (52\%), Amhara (30\%) and SNNPR (11\%) regions [31-38]. The Oromia and Amhara regions share boundaries with many other regions in Ethiopia and are likely to share common flora and cultural practices, including in ethno-medicine. This long list of species also indicates that local people in these regions have an active interest in $E$. kebericho species. Moreover, the geographic distribution of Echinops kebericho Mesfin is likely to be predicated on local trend with regard to cultural and floral diversity including traditional medicinal practices. [39], and [40], reported that the plant belongs to the genus Echinops that comprises 125-130 species in the family Asteraceae/Compositae distributed in semi-humid zones of tropical and North Africa, Mediterranean basin, and temperate regions up to Central Asia. The twelve species of E. kebericho belongs to the Asteraceae family occur in Ethiopia are also confined to the highlands of the country between $7^{\circ} 30^{\prime} \mathrm{N}$ and $38^{\circ} 45^{\prime} \mathrm{E}$ and at altitudes between 1700 and 2900 m.a.s.l [41]. E. kebericho grows in dry and stony lateritic soils. It is different in habit and in dissection of the leaf blade. These plant populations in deep vertisols are low shrubs whereas those growing in dry, stony lateritic soils are perennial herbs [41]. 
Table 1. Reported therapeutic Use of Echinops Kebericho Mesfin in Ethiopia.

\begin{tabular}{|c|c|c|c|c|}
\hline Diseases treated & Part used & Application & Region & Reference \\
\hline Mosquitoes & Root & Dried parts burned to generate smoke & Oromia & [42] \\
\hline Toothache & Root & Fresh root paste with water is given orally & Oromia & [26] \\
\hline $\begin{array}{l}\text { Abdominal aches } \\
\text { Circling disease } \\
\text { Coughing (L) }\end{array}$ & Root & $\begin{array}{l}\text { The roots chopped and given with feed. Its root chopped, added to fire and } \\
\text { smoked }\end{array}$ & Oromia & [43] \\
\hline Coughing & Root & Infusion & & \\
\hline Head ache & Root & Smoke & Oromia & [44] \\
\hline Fibre illness & Root & Smoke & & \\
\hline Fibre illness & Root & Smoke & & {$[211]$} \\
\hline Evil eye & & Not specified & Oromıa & {$[21]$} \\
\hline Toothache & Root & Pounded dry root is mixed with coffee & Oromia & [31] \\
\hline $\begin{array}{l}\text { Black leg } \\
\text { Respiratory, Liver }\end{array}$ & Root & $\begin{array}{l}\text { Root is powdered and mixed with pulverized leaves to make decoction } \\
\text { Not specified }\end{array}$ & Oromia & [38] \\
\hline Evil eye & Root & & & \\
\hline Evil sprit & Root & Not specified & Amhara & [35] \\
\hline $\begin{array}{l}\text { Malaise } \\
\text { Fever }\end{array}$ & $\begin{array}{l}\text { Root } \\
\text { Root }\end{array}$ & 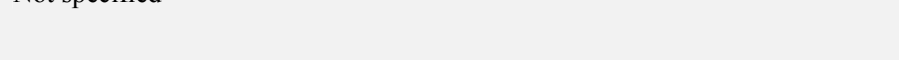 & 1 & \\
\hline Evil eye & Root & Drying, crushing and adding the seed on fire to smell & & \\
\hline Tape worm & Root & Drying and crushing then drink by Mixing with Capsicum annuиm L. and salt & & [37] \\
\hline Common cold & Root & Burning the root and inhale it & Amhara & {$[37]$} \\
\hline Febrile illness & Root & Not specified & & \\
\hline Evil eye & Root & Dried root is applied to smoking orally. & & \\
\hline Mitat & Root & Dried root is smoking orally. & Amhara & [32] \\
\hline Evil eye & Root & Smelling and inhaling & Amhara & {$[34]$} \\
\hline Mitat & Root & Smelling and inhaling & Ammara & [34] \\
\hline Epidemic diseases & Root & fumigated & Amhara & [33] \\
\hline Evil eye & $\begin{array}{l}\text { Above } \\
\text { ground }\end{array}$ & Feces of donkey are added with it and add in to fire then expose to the smoke. & Tigray & [45] \\
\hline Toothache & Root & & & \\
\hline Sunstrik (meganya) & Root & & & \\
\hline Acute sickness & Root & & & \\
\hline Tonsillitis & leaf & Not specified & SNNPR & [36] \\
\hline Common cold & Root & & & \\
\hline Snake bite & Root & & & \\
\hline Stomachache & Root & & & \\
\hline Malaria & Root & $\begin{array}{l}\text { Roots are crushed with seeds of Guizotia abyssinica, mixed with water and } \\
\text { solution taken orally }\end{array}$ & Amhara & [46] \\
\hline Abortifacient & Root & & & \\
\hline Epilepsy & Root & & & \\
\hline Epistaxis & Root & & & \\
\hline Atrophy & Root & Not specified & SNNPR & [47] \\
\hline Devil sickness & Root & & & \\
\hline Dingategna & Root & & & \\
\hline Tonsillitis & Root & & & \\
\hline Evil eye & Root & The same as Carisa edulis and Caparis tomentosa. & Oromia & \\
\hline Head ache & Root & Dry root is smoked to the patient. & & [27] \\
\hline Parasite & Root & $\begin{array}{l}\text { Root is pounded together with leaf of } \\
\text { Vernonia amygdalina and given to cattle as feed. }\end{array}$ & & {$[21]$} \\
\hline $\begin{array}{l}\text { Malaria } \\
\text { common cold }\end{array}$ & $\begin{array}{l}\text { Root } \\
\text { Root }\end{array}$ & $\begin{array}{l}\text { Inhaling the root powder } \\
\text { Inhaling the root powder }\end{array}$ & Amhara & [48] \\
\hline Evil eye & Root & Root powder is sprinkled on burning charcoal and smoke is inhaled & Oromia & [49] \\
\hline Cough, & Root & Bulbs are infused, inhaled, and smoked. & SNNPR & {$[50]$} \\
\hline $\begin{array}{l}\text { Dislocated bone } \\
\text { (livestock) }\end{array}$ & Root & Tie it on damaged part & Tigray & [51] \\
\hline Fever & Root & Inhale the smoke & & \\
\hline Typhoid & Root & & & \\
\hline Tonsilitis & Root & & & \\
\hline Tooth ache & Root & & & \\
\hline Common cold & Root & & & \\
\hline Cancer & Root & Not specified & Oromia & [52] \\
\hline Insect repellent & Root & Not specinted & & \\
\hline Hypertension & Root & & & \\
\hline Colic & Root & & & \\
\hline Evil eye & Root & & & \\
\hline Evil spirits & Root & & & \\
\hline
\end{tabular}




\subsection{Therapeutic Uses of Echinops Kebericho Mesfin}

A survey of literatures showed several medicinal properties have been attributed to Echinops kebericho Mesfin in different regions of Ethiopia. The traditional uses of Echinops is referred to many folkloric and ethnobotanical studies done in Ethiopia, where the species is still used as primary sources of traditional medicine. A total of 32 human and 2 animal ailments are treated with Echinops kebericho (Table 1). [51] and [53] also showed the majority of medicinal plants were used to treat human diseases than livestock due to high prevalence of human diseases. But, [26] observed that local communities give priority for human health care than livestock due to inadequate modern healthcare centers in the study area till traditional healers are using local plants for the welfare of human health. The most commonly treated human ailments are evil eye followed by headache, cough, stomachache, febrile illness and malaria. Other studies conducted elsewhere in Ethiopia indicated the evil eye as common mental disorders $[24,54,55]$. The previous study in Dega Damot, Amhara, North western Ethiopia also showed that $34 \%$ of informants reported Echinops kebericho used to treat evil eye in the district [37]. Similarly, study around Dirre Sheikh Hussein, South-eastern Ethiopia [53] found that, Echinops kebericho Mesfin was frequently mentioned medicinal plant. The comparison of earlier ethnobotanical studies conducted in Ethiopia showed that, many similarities can be recognized when the ethnomedicinal uses of Echinops kebericho is considered in all regions (Table 1). This may imply that, local people of Ethiopia over wide area have the tendency to use the similar medicinal plant as a result of the wider distribution of medicinal plants in the country [33] and due to same selection criteria. On the top of this, similar uses of Echinops kebericho in different regions of country also showed the considerable dissimilarity with respect to preparation and application techniques. According to this review, traditional medicinal practitioners in Ethiopia apply different techniques of preparations including, crushing, powdering, and chopping (Table 1). They use simple techniques and equipments during their remedy preparation. For instance, powder of Echinops root is given to patients suffering evil eye by inhaling and roots are crushed with seeds of Guizotia abyssinica, mixed with water and solution taken orally $[32,34,37,42,46]$. Medicinal preparations from Echinops kebericho Mesfin have been suggested to shorten the course of illness from black leg, respiratory manifestations and liver disease [38]. Moreover, the smoke from burning the plant is inhaled to relieve headache $[27,31,32,34,44,50]$. Echinops kebericho is traditionally used for the treatment of fibre illness, evil spirit, snake bite, tonsillitis, coughing and sudden illness [35, 36, 43, 56].

Traditional healers prepare herbal remedies either solely or in combinations and for oral use with water or other additives such as honey, sugar and mixing with other plant. The majority of the Echinops kebericho remedies (87.3\%) are used as monotherapies. The review is in agreement with the finding of [53], which stated that single plant remedy preparations were high. However, multi therapies/ a mixture of Echinops kebericho root pounded together with leaf of Vernonia amygdalina given for cattle as a remedy for parasite [27]. Pounded dry root is mixed with coffee used for headache [31]. E. kebericho roots are crushed with seeds of Guizotia abyssinica, mixed with water and solution taken orally for treatment of malaria [46]. The use of multiple therapies in traditional medicine based on combining plants has recently been shown to increase the efficacy of the herbal medicine [57]. Study by [58], showed that the use of more than one plant species to prepare a remedy for ailments is attributed to the synergistic effects that they could have during ailment treatment.

In this review, root was the most commonly used plant part in the preparation of remedies as compared to other parts. [6, $48,59]$ also found roots take the highest proportion in remedy preparation due to the efficacy of roots in treating the ailments. Study conducted in South Omo, Southern Ethiopia [60], indicated that roots remain in the soil and is easily available, even during the long dry seasons in arid and semi-arid areas. Moreover, the use of plants root could also be associated with early African beliefs in their powerful therapeutic effect to protect malaria and venereal diseases and to induce abortions $[61,62]$. However, other studies conducted elsewhere in Ethiopia showed harvesting root of a plant poses more threat to survival of plant than collecting other parts such as fruits, seeds and leaves [63, 64]. Similarly, [65], found that Echinops kebericho was a critically endangered medicinal plant due commercial harvesting and sale of roots. Moreover, study conducted in West Gojjam Ethiopia [33] revealed that Echinops kebericho was approaching to extinct due to overharvesting root for medicine. But a study done in Guraghe zone, SNNPR of Ethiopia [66] indicated that $66 \%$ of Echinops kebericho threatened because of agricultural expansion.

\subsection{Ethnopharmacological Properties}

\subsubsection{Antimicrobial Activity}

The present review reported the extract of E. Kebericho root exhibited good antibacterial and antifungal activity. Report says that alcohol extracted from E. Kebericho root believed to be responsible for control against $S$. aureus $A$. flavus and C. albicans [67]. But, water based extracts showed weak antimicrobial activity. The higher polyphenols present in alcohol based extracts was found to posses stronger antimicrobial activity than water based extract.

\subsubsection{Antimalarial Activity}

Malaria is a world public health threat infecting about 300 million people each year [68]. Thus, medicinal plants are being commonly used to treat malaria due to the presence of anti plasmodial compounds [69]. Experiments by [70], demonstrated that $E$. Kebericho root extract in fraction of hexane and butanol have antimalaria activity with an optimal dose of $500 \mathrm{mg} / \mathrm{kg}$ body weight. Root extractof E. Kebericho 
in crude ethanol showed parasitemia and extending the survival time of mice [15]. The extracts of E. Kebericho showed antiplasmodial activities against Plasmodium Berghei which supports traditional uses of species [71]. E. Kebericho Mesfin is also among traditionally used medicinal plants against wide ranges of diseases including malaria in Ethiopia $[18,72]$, showed that Sesquiterpenes compounds obtained from Echinops species exhibited antimalarial agents activities.

\subsubsection{Antidiarrheal and Ant Spasmolytic Activities}

Diarrhea is a widespread gastrointestinal disorder caused by infections. It is responsible for deaths of 5 million human populations every year [73, 74]. The present review reported the root extract of Echinops kebericho is used traditionally for the treatment of diarrhea in Ethiopia. [75], conducted an experiment with aqueous extracts from E. kebericho for its protective effect against diarrhea and spasmodic. This research confirms the use of extract of Echinops kebericho possesses antidiarrheal and spasmolytic activities.

According to [76] flavonoid is collection of polyphenolic compound and has been confirmed to exhibit a different of biological activities for example antioxidant, anti-inflammatory, antispasmodic, and antidiarrheal effects. Study by [77] reported that the antidiarrheal activity of flavonoids to inhibit intestinal motility and hydro-electrolytic secretions.

\subsubsection{Oral Acute Toxicity Activities}

Many plants produce biologically active substance which can poison, kill and repel other species. [71] demonstrated that the graded doses of $70 \%$ methanol extract of $E$. Kebericho Mesfin did not exhibit any signs of toxicity in mice. Experiments by [15] confirmed that E. kebericho extract in hydro-alcoholic did not produce significant changes in behaviors, such as alertness, motor activity, breathing, restlessness, diarrhoea, convulsions, coma, and appearance of the animals. Research by [78] showed that the people in the central and south-western parts of Ethiopia use the smoke of $E$. kebericho to repel snakes from their vicinity. These results confirm that natural products from Echinops species are potential sources of new and selective agents for the treatment of important diseases.

\subsubsection{Antileishmanial Activity}

Leishmaniasis is a disease caused by obligate intracellular parasitic protozoa of the genus Leishmania [79]. According to [80], leishmaniasis is transmitted to humans and other mammals by the bite of infected females and flies vector. For the past decade, there have been a few studies conducted concerning the antileishmanial activity of phytochemicals of Echinops kebericho. In one pharmacological study, essential oils extract of Echinops kebericho was found to be highly active as antileishmanial activities [17].

\subsection{Major Threats to Echinops Kebericho}

Currently, many medicinal plants are being seriously depleted in Ethiopia due to anthropogenic factors [45, 81], agricultural expansion, deforestation, fuel wood harvesting, overgrazing and urbanization [82, 83]. Echinops kebericho has been registered under national red list as vulnerable since it is facing a high risk of extinction in the wild, mainly associated with its traditional medicinal use [84]. Study conducted in Tembaro Zone, Southern Ethiopia [85] showed that Echinops kebericho, was marketed mainly for therapeutic purpose to generate income. The first report made by [86] revealed the popularity of $E$. kebericho trade in all 19 markets of central parts Ethiopia. The numerous tuberous roots are sold as small pieces or in entire in many markets in Gojjam, Shewa and Wellega [29]. According to [87], the use and practices related with traditional fumigation of E.kebericho isa vital after birth in many parts of Ethiopia. For instance, a study in Borana, southern Ethiopia showed that E.kebericho has been reported to have abortifacation effect, and also used to care forepilepsy, epistaxis, atrophy, sudden, evil spirit sickness by people of Kembatta, Southern Ethiopia [85]. Thus, due to its over use in the wild the species is facing a high risk of extinction in the wild.

Echinops kebericho Mesfin is known as seriously endangered endemic shrubs of Ethiopia [88]. Study conducted in Mecha Wereda, West Gojjam Zone of Amhara region [14], indicated that E. kebericho is insufficient medicinal plant due to overexploitation. Moreover, the natural regeneration status of E. kebericho is restricted to a particular microclimate; the domestication of this species is very difficult. E. kebericho reproduce by seed which is incompetent due to inadequate and in viability of seeds. Propagation by seeds is time consuming to achieve large scale production for preservation and farming of the species. Despite these problems, the local people destruct the whole plant before seed set as they use the root part for medicinal use. Generally, a problem related with natural propagation and overexploitation for medicinal use has put E. kebericho in the list of critically endangered plant species of Ethiopia [89]. It is among few prioritized medicinal plants of Ethiopia that needs urgent conservation. The micropropagation of E. kebericho is very useful to preserve germplasm of this endangered species, to promote scientific activities, commercial cultivation and sustainable usage of the species. Study by [90], reported the in vitro and ex vitro seed based propagation of E. kebericho. Other study has also showed that micropropagation of Echinops kebericho has a considerable practical significance for large scale production of plants for their rehabilitation in natural habitat, ex vitro cultivation and sustainable utilization of this medicinal plant [65].

\section{Conclusion and Recommendations}

The extensive literatures survey revealed that Echinops kebericho Mesfin is important medicinal plant with diverse pharmacological spectrum. The plant shows the presence of many chemical constituents which are responsible for varied pharmacological and medicinal properties. The pharmacological analysis will also highlight how the limited population numbers of the plant can be utilized as source of 
medicine. Although Ethiopian Echinops kebericho is widely used by traditional practitioners for curing various diseases, it is threatened due to over exploitation of root part; hence urgent conservation attention is needed to conserve this species for sustainable usage in the future. Moreover, the present researchers believe that the therapeutic use of the $E$. kebericho will provide basic data for further researches focus on pharmacological studies and the conservation of this most endangered and endemic medicinal plant in Ethiopia.

\section{Authors' Contributions}

Gadisa Demie is a lecturer at Department of Forestry College of Agriculture and Veterinary Science, Ambo University, Ethiopia. He planned the Review, searched data, analyzed the data and wrote the manuscript.

\section{References}

[1] Dolatkhahi, M., Dolatkhahi, A., Nejad, JB. (2014): Ethnobotanical study of medicinal plants used in ArjanParishan protected area in Fars Province of Iran. Avicenna J Phytomed, 4: 402-12.

[2] Shendye, NV., Gurav, SS. (2014): Cynodon dactylon: A Systemic Review of Pharmacognosy, Phytochemistry and Pharmacology. Int J Pharm Pharm Sci 8: 7-12.

[3] Shah, A., Marwat, SK., Gohar, F., Khan, A., Bhatti, KH., Amin, M. (2013): Ethnobotanical study of medicinal plants of semi-tribal area of Makerwal \& Gulla Khel (lying between Khyber Pakhtunkhwa and Punjab Provinces), Pakistan. Am J Plant Sci, 4: 98-116.

[4] Hostettmann, K., Marston, A., Ndjoko, K., Wolfender, J-L. (2000): The Potential of African Medicinal Plants as a Source of Drugs. Current Organic Chemistry, 4: 973-1010.

[5] Gidey, M., Beyene, T., Signorini, MA., Bruschi, P., Yirga, G. (2015): Traditional medicinal plants used by Kunama ethnicgroup in Northern Ethiopia. Journal of Medicinal Plants Research15: 94-509.

[6] Lulekal, E., Kelbessa, E., Bekele, T., Yineger, H. (2008): An ethnobotanical study of medicinal plants in Mana AngetuDistrict, southeastern Ethiopia. Journal of Ethnobiology and Ethnomedicine, 4: 10.

[7] Yassin, S., Abera, B., Kelbessa, E. (2015): Ethnobotanical study of indigenous knowledge of plant-material culture in Masha and Yeki Districts, Southwest Ethiopia. Afr J Plant Sci 9: 25-49.

[8] Hunde, D., Jesse, T., Asfaw, Z., Nyangito, MM. (2011): Wild edible fruits of importance for human nutrition in semiarid parts of East Shewa zone, Ethiopia: associated indigenous knowledge and implications to food security. J. Nutr, 10: 40-50.

[9] Bekele, E. (2007): Study on Actual Situation of Medicinal Plants in Ethiopia; 77. Available from 〈http://www.endashaw.com $\rangle$.

[10] Bahmani, M., Rafieian-Kopaei, M., Avijgan, M., Hosseini, S., Golshahi, H., Eftekhari, Z. (2012): Ethnobotanical studies of medicinal plants used by Kurdish owner's in south range of Ilam province, west of Iran. Am Eurasia J Agric Environ Sci,

\section{2: $1128-33$.}

[11] Savithramma, N., Ankanna, S., Linga, RM., Saradvathi, J. (2012): Studies on antimicrobial efficacy of medicinal tuberous shrub Talinum cuneifolium. J Environ Biol 33: 775-80.

[12] Deka, M., Kalita, JC., Sarma, GC. (2011): Traditional use of fertility inducing plants used by the herbal practitioners in some parts of the state Assam, N E India, a survey report. International Journal of Science and Advanced Technology, 1: $133-142$.

[13] Robert, H., John, B. (1983): Traditional medicine and health carecoverage. WHO; 1983.

[14] Belay, G., Tariku, Y., Kebede, T., Hymete, A., Mekonnen, Y. (2011): Ethnopharmacological Investigations of Essential Oils Isolated from Five Ethiopian Medicinal Plants against Eleven Pathogenic Bacterial Strains. Phytopharmacology, 1: 133-143.

[15] Toma, A., Deyno, S., Fikru, A., Eyado, A., Beale, A. (2015): In vivo antiplasmodial and toxicological effect of crude ethanol extract of Echinops kebericho traditionally used in treatment of malaria in Ethiopia. Malaria Journal 14: 196.

[16] Abegaz, B., Mutanyatta-Comar, J., Nindi, M. (2007): Naturally Occurring Homoiso flavonoids: Phytochemistry, Biological Activities and Synthesis. Natural Product Communications 2: 475-498.

[17] Tariku, Y., Hymete, A., Hailu, A., Rohloff, J. (2011): In Vitro Evaluation of Antileishmanial Activity and Toxicity of Essential Oils of Artemisia absinthium and Echinops kebericho. Chemistry \&Biodiversity8: 614-623.

[18] Hymete, A., Rohloff, J., Iversen, TH., Kjosen, H. (2007): Volatile Constituents of the Roots of Echinops kebericho Mesfin. Fla. and Fragr J22: 35-38.

[19] Jemal, H., Kaba, U., Fayissa, R., Awol, J., Sultan, A., Nazif, H. (2011): Antihelmentic Effects of the Essential Oil Extracts of Selected Medicinal Plants against Haemonchus contortus. International Journal of Agricultural Research6: 290-298. http://dx.doi.org/10.3923/ijar.2011.290.298.

[20] Bekalo, TH., Woodmatas, SD., Woldemariam, ZA. (2009): Anethnobotanical study of medicinal plants used by localpeople in the lowlands of Konta Special Woreda, southern nations, nationalities and peoples regionalstate, Ethiopia. J. Ethnobiol Ethnomed 5: 26 doi: 10.1186/1746-4269-5-26.

[21] Wondimu, T., Asfaw, Z., Kelbessa, E. (2007): Ethnobotanical study of medicinal plants around'Dheeraa' town, Arsi Zone, Ethiopia Journal of Ethnopharmacology 112: 152-161.

[22] Getachew, B., Yinebeb, T., Taddesse, K., Ariaya, H., Yalemtsehay, M. (2011): Ethnopharmacological Investigations of Essential Oils Isolated from Five Ethiopian Medicinal Plants against Eleven Pathogenic Bacterial Strains. Phytopharmacology, 1: 133-143.

[23] Demissew, S. (1993): Description of some essential oil bearing plants in Ethiopia and their indigenous uses. J Essent Oil Res, 5: 465-479.

[24] Ayalew, S., Kebede, A., Mesfin, A., Mulualem, G. (2017): Ethnobotanical study of medicinal plants used by agropastoralist Somali people for the management ofhuman ailments in Jeldesa Cluster, Dire DawaAdministration, Eastern Ethiopia. J. Med. Plants Res, 9: 171-187. 
[25] Desta, B. (1995): Ethiopian traditional herbal drugs. Part I: Studies on the toxicity and therapeutic activity of local taenicidal medications. Journal of Ethnopharmacology, 45: $27-33$

[26] Enyew, A., Asfaw, Z., Kelbessa, E., Nagappan, R. (2014): Ethnobotanical Study of Traditional Medicinal Plants in and Around Fiche District, Central Ethiopia. Curr. Res. J. Biol. Sci, 4: $154-167$.

[27] Kassa, Z., Asfaw, Z., Demissew, S. (2016): Ethnobotanical study of medicinal plants used by thelocal people in Tulu Korma and its Surrounding Areas of Ejere District, Western Shewa Zone ofOromia Regional State, Ethiopia. JMPS, 2: $24-47$

[28] Megersa, M., Asfaw, Z., Kelbessa, E., Beyene, A., Woldeab, B. (2013): An ethnobotanical study of medicinal plants in Wayu Tuka District, East Welega Zone of Oromia Regional State, West Ethiopia. Journal of Ethnobiology and Ethnomedicine, 9: 68.

[29] Tadesse, M., Mesfin, B. (2010): A review of selected plants used in the maintenance of health and wellness in Ethiopia. Ethiopiane-journal Research \& Innovation foresight 1: 85-102.

[30] Tekle, Y. (2014): An ethno-veterinary botanical survey of medicinal plants in Kochore district of Gedeo Zone, Southern Nations Nationalities and Peoples Regional State (SNNPRs), Ethiopia. JSIR, 4: 433-445.

[31] Abera, B. (2014): Medicinal plants used in traditional medicine byOromo people, Ghimbi District, Southwest Ethiopia. Journal of Ethnobiology and Ethnomedicine 10: 40.

[32] Asmamaw, D., Achamyeleh, H. (2018): Assessment of Medicinal Plants and Their Conservation Status in Case ofDaligaw Kebela, Gozamen Werda, East Gojjam Zone. J Biodivers Bio, 1: 170 .

[33] Gebeyehu, G., Asfaw, Z., Enyew, A., Raja, N. (2014): Ethnobotanical study of traditional medicinal plants and their conservation status in Mecha wereda, West Gojjam zone of Ethiopia. Int. J. Pharm. \& H. Care Res, 03: 137-154.

[34] Getnet, Z., Chandrodyam, S., Masresha, G. (2016): Studies on traditional medicinal plants in Ambagiorgis area of Wogera District, Amhara Regional State, Ethiopia. Int. J. Pure App. Biosci, 4: 38-45.

[35] Lulekal, E., Asfaw, Z., Kelbessa, E., Damme, PV. (2013): Ethnomedicinal study of plants used for human ailments in Ankober District, North Shewa Zone, Amhara Region, Ethiopia. J Ethnobiol Ethnomed 9: 63.

[36] Regassa, R. (2013): Assessment of indigenous knowledge of medicinal plant practice and mode of service delivery in Hawassa city, southern Ethiopia. Journal of Medicinal Plants Research, 9: 517-535.

[37] Wubetu, M., Abula, T., Dejenu, G. (2017): Ethnopharmacologic survey of medicinal plants used to treat human diseases by traditional medical practitioners in Dega Damot district, Amhara, Northwestern Ethiopia. BMC Res 10: 157 DOI 10.1186/s13104-017-2482-3.

[38] Yigezu, Y., Berihun, D., Yenet, W. (2014):. Ethnoveterinary medicines in four districts of Jimma zone, Ethiopia: cross sectional survey for plant species and mode of use. BMC Veterinary Research 10: 76.
[39] Hedberg, I., Friis, I., Edwards, S. (2004): Flora of Ethiopia and Eritrea. Vol. 4, part 2', Addis Ababa University, Addis Ababa 221-223.

[40] Teresa, G., Susanna, A., Garcia-jacas, N., Vilatersana, R., Vall, J. (2005): A first approach to the molecular phylogeny of the genus Echinops (asteraceae): sectional delimitation and relationships with the genus, Acantholepis. Fotia Geobotanica 40: 407-419.

[41] Erko, B. (2006): Screening of Echinops ellenbeki and E. longisetus for biological activities and chemical constitutes. [C] 2005 Elsevier GmbH. http://www.wormdigest.org

[42] Karunamoorthi, K., Hailu, T. (2014): Insect repellent plants traditional usage practices in the Ethiopian malaria epidemic-prone setting: an ethnobotanical survey. Journal of Ethnobiology and Ethnomedicine 10: 22.

[43] Feyissa, FT., Shigut, MM., Hailemariam, Tilahun, BT., Regassa, T., Kergano, NK. (2017): Ethnobotanical study of ethnoveterinary plants in Kelem Wollega Zone, Oromia Region, Ethiopia, 16: 307-317.

[44] Teklehaymanot, T., Giday, M., Medhin,. G, Mekonnen, Y. (2006): Knowledge and use of medicinal plants by people around Debre Libanos monastery in Ethiopia. Journal of Ethnopharmacology doi: 10.1016/j.jep.2006.11.019.

[45] Giday, M., Teklehaymanot, T., Animut, A., Mekonnen, Y. (2007): Medicinal plants of the Shinasha, Agew-awi and Amhara people sin northwest Ethiopia. J. Ethnopharmacol, 110: 516-525.

[46] Birhan, YS., Kitaw, SL., Alemayehu, YA., Mengesha, NM. (2018): Ethnobotanical study of medicinal plants used to treat human diseases in Enarj Enawga District, East Gojjam Zone, Amhara Region, Ethiopia. SM J Med Plant Stud 1: 1006.

[47] Maryo, M. (2013): Enset-Based Agrobiodiversity in the Agricultural Landscape of Kambatta Tembaro, Southern Ethiopia. A Thesis Submitted to the Department of Plant Biology and Biodiversity management Presented in Fulfillment of the Requirements for the Degree of Doctor of Philosophy (Biology: BotanicalScience). Addis Ababa University, Ethiopia.

[48] Mekuanent, T., Zebene, Z., Solomon, Z. (2016): Ethnobotanical Study of Medicinal Plants in Chilga District, Northwestern Ethiopia. Journal of Natural RemediesDOI: $10.18311 /$ jnr/2015/476.

[49] Teklehaymanot, T., Giday, M. (2007): Ethnobotanical study of medicinal plants used by people in ZegiePeninsula, Northwestern Ethiopia. Journal of Ethnobiology and Ethnomedicine, 3: 12.

[50] Mesfin, F., Seta, T., Assefa, A. (2014): An Ethnobotanical Study of Medicinal Plants in Amaro Woreda, Ethiopia. Ethnobotany Research \& Applications 12: 341-354.

[51] Teklay, A., Abera, B., Giday, M. (2013): An ethnobotanical study of medicinal plants used in Kilte Awulaelo District, Tigray Region of Ethiopia. Journal of Ethnobiology and Ethnomedicine 9: 65.

[52] Kloos, H., Menberu, T., Tadele, A., Chanie, T., Debebe, Y., Abebe, A., Zealiyas, K., Tadele, G, Mohammed, M., Debella, A. (2014): Traditional medicines sold by vendors in Merkato, Addis Ababa: Aspects of their utilization, trade, and changes between 1973 and 2014. Ethiop. J. Health Dev, 28: 2. 
[53] Demie, G., Negash, M., Awas, T. (2018): Ethnobotanical study of medicinal plants used by indigenous people in andaround Dirre Sheikh Hussein heritage site of South-eastern Ethiopia. Journal of Ethnopharmacology, 220: 87-93.

[54] Belayneh, A., Asfaw, Z., Demissew, S., Bussa, NF. (2012): Medicinal plants potential and use by pastoral and agro-pastoral communities in Erer valley of Babile Wereda, eastern Ethiopia. J Ethnobiol Ethnomed 1: 42.

[55] Misha, G., Yarlagadda, R., Wolde-Mariam, M. (2014): Knowledge, attitude, practice and management of traditional medicine among people of Shopa Bultum, southeast Ethiopia. Res J Pharm Biol Chem Sci, 5: 152-170.

[56] Tirfessa, K., Belude, T., Denu. (2017):Ethnobotanical study of medicinal plants in Akakidistrict, East Shewa Zone, Oromia regional state, Ethiopia. Journal of Medicinal Plants Studies, 2: 353-360.

[57] Zonyane, S., Van Vuuren, SF., Makunga, NP. (2012): Pharmacological and phytochemical analysis of a medicinal plant mixture that is used as traditional medicine in Western Cape. Paper presented at South Africa Association of Botanist 38th Annual Conference, 15-18 January 2012. University of Pretoria, Pretoria; 124.

[58] Bussman R W, Sharon D. (2006): Traditional medicinal plant use in Northern Peru: tracking two thousand years of healing culture. Journal of Ethnobiology and Ethnomedicine, 2: 47, doi: $10.1186 / 1746-4269-2-47$.

[59] Flatie, T., Gedif, T., Asres, K., Gebre-Mariam, T. (2009): Ethnomedical survey of Berta ethnic group Assosa Zone, Benishangul-Gumuz regional state, mid-west Ethiopia. Journal of Ethnobiology and Ethnomedicine, 5: 14, doi: 10.1186/17464269-5-14.

[60] Tolossa, K., Debela, E., Athanasiadou, S., Tolera, A., Ganga, G., Houdijk, JGM. (2013): Ethno-medicinal study of plants used for treatment of human and livestock ailments by traditional healers in South Omo, Southern Ethiopia. Journal of Ethnobiology and Ethnomedicine 9: 32.

[61] Van Andel, T., Mitchell, S., Volpato, G., Vandebroek, I., Swier, J., Ruysschaer, S., Jiménez, CAR., Raes, N. (2012): In search of the perfect aphrodisiac: Parallel use of bitter tonics in West Africa and the Caribbean. J Ethnopharmacol 143: 840-850.

[62] Voeks, RA. (2009): Traditions in Transition: African diaspora ethnobotany in Low land South America. In Mobility and migration in indigenous Amazonia: contemporary ethnoecological perspectives. Edited by Alexiades M. London: Beghahn Books; 275-294.

[63] Ragunathan, M., Abay, SM. (2009): Ethnomedicinal survey of folk drugs used in Bahirdar Zuria District, Northwestern Ethiopia. Indian J Traditional Knowledge 2009, 8: 281-284.

[64] Aschale, Y., Wubetu, M., Reta, H. (2018): Ethnobotany of Medicinal Plants Used to Treat Leishmaniasis in Ethiopia: A Systematic Review. Tradit Med Clin Natur, 7: 2

[65] Manahlie, B., Feyissa, T. (2014): Micropropagation of Kebericho: AnEndandered Ethiopian Medicinal Plant. American Journal of Plant Sciences, 5: 3836-3847.

[66] Bizuayehu, B., Assefa, T. (2017): Ethnobotanical value of medicinal plant diversity in Cheha district, Guraghe zone, Southern Nations, Nationalities and Peoples (SNNPR) of Ethiopia. J. Med. Plants Res, 28: 445-454.
[67] Ameya, G., Gure, A., Dessalegn, E. (2016): Antimicrobial activity of Echinops kebericho against human pathogenic bacteria and fungi. Afr J Tradit Complement Altern Med, 6: 199-203.

[68] World Health Organization: "World malaria report". WHO Press, Geneva, Switzerland; 2014.

[69] Mesfin, A., Giday, M., Animut, A., Teklehaymanot, T. (2012): Ethnobotanical study of antimalarial plants in Shinile District, Somali Region, Ethiopia, and in vivo evaluation of selected ones against Plasmodium berghei. Journal of Ethnopharmacology 1: 221-7.

[70] Toma, A., Deyno, S., Eyado, A., Fikru, A. (2017): In Vivo Antimalarial Activity of Solvent Fractions of Echinops kebericho Rootsagainst Plasmodium berghei Infected Mice. EC Microbiology 12.5: 204-212.

[71] Biruksew, A., Zeynudin, A., Alemu, Y., Golassa, L., Yohannes, M., Debella, A., Urge, G., Spiegeleer, B D., Suleman, S. (2018): Zingiber Officinale Roscoe and Echinops Kebericho Mesfin Showed Antiplasmodial Activities against Plasmodium Berghei in a Dose dependent Manner in Ethiopia. Ethiopian journal of health sciences, 28: 5.

[72] Jansen, O., Tits, M., Angenot, L., Nicolas, J-P., DeMol, P., Nikiema, J-B. (2012): Anti-plasmodial activity of Dicoma tomentosa (Asteraceae)and identification of urospermal A-15-Oacetateas the main active compound. Malar J 11: 289.

[73] Adeyemi, OO., Akindele, AJ. (2008): Antidiarrheal activity of the ethyl acetate extract of Baphia nitida. J. Ethnopharmacol, 116: 407-412.

[74] Prashant, BS. (2012): Significance of Black pepper in Ayurvedic antidiarrhoeal formulation. J. Chem Pharm Res, 4: 2162-2166. pros Dev. 5: 1 DOI: 10.4172/2376-0214.1000170.

[75] Shiferie, F., Shibeshi, W. (2013): In vivo antidiarrheal and ex-vivo spasmolytic activities of the aqueous extract of the roots of Echinops kebericho Mesfin (Asteraceae) in rodents and isolated guinea-pig ileum. Int. J. Pharm. Pharmacol, 7: $110-116$.

[76] Hu, J., Gao, W., Ling, N., Liu, C. (2009): Antidiarrheal and intestinal modulatory activities of Wei-Chang-An-Wan extract. J. Ethnopharmacol 125: 450-455.

[77] Meite, S., Nguessan, DJ., Bahi, C., Yapi, HF., Djaman, AJ., Guina, FG. (2009): Antidiarrheal activity of the ethyl acetate extract of Morinda morindoides in rats. Trop. J. Pharm. Res, 3: 201-207.

[78] Kloss, H. (1977): Ethnomedicine, 4: 63-104.

[79] Grimaldi, G., Tesh, R. (1993): Leishmaniasis of the New World: current concepts and implications for future research. Clin Microbiol Rev, 6: 230-250.

[80] Ready, PD. (2013): Biology of phlebotomine sand flies as vectors of disease agents. Annu Rev Entomol 58: 227-250.

[81] Birhane, E., Aynekulu, E., Mekuria, W., Endale, D. (2011): Management, use and ecology of medicinal plants in the degraded dry lands of Tigray, Northern Ethiopia. J. Horticul. For 2: 32-41.

[82] Mesfin, K., Tecle, G., Tesfay, T. (2013): Assessment of threatening factors of medicinal plant species in Samre district, South-eastern Tigray, northern Ethiopia. J. Med. Plant Stud, 4: 38-43. 
[83] Khan, SM., Page, S., Ahmad, H., Harper, DM. (2012): Anthropogenic influences on the natural ecosystem of the Naran Valley in the Western Himalayas Pakistan. Pak. J. Bot, 2: 231-238.

[84] Erenso, F., Maryo, M. (2014). Endemic plant species composition and their status in Boda Dry Evergreen Montane Forest, West Showa, Ethiopia. Int. J. Biodivers. Conserv, 7: 563-569.

[85] Maryo, M., Nemomissa, S., Bekele, T. (2015): An ethnobotanical study of medicinal plants of the Kembatta ethnic group in Enset-based agricultural landscape of Kembatta Tembaro (KT) Zone, Southern Ethiopia. Asian Journal of Plant Science and Research, 5 (7): 42-61.

[86] Kloos, H. (1976): Preliminary studies of medicinal plants and plant products in Ethiopian markets. J. Ethiop. Pharm. Assoc, 4: 63-102.
[87] Dalle, G., Maass, BL., Isselstein, J. (2005): Plant Biodiversity and Ethnobotany of Borana Pastoralists in Southern Oromia, Ethiopia. Economic Botany, 1: 43-65.

[88] Turek, I., Carvahlo, MSR., Wube, A., Bucar, F. (2016): Headspace analysis of the smoke of Echinops kebericho Mesfin. Conference Paper.

[89] Global Environment Facility: Capacity Building for Access and Benefit Sharing and Conservation and Sustainable Use of Medicinal Plants. Ethiopia ABS CSUMP CEO Endorsement Document; 2012.www.theGEF.org

[90] Balcha, A., Legesse, N., Jochen, K. (2009): In Vitro and ex Vitro Seed-Based Propagation Methods of Echinops kebericho Mesfin: A Threatened Medicinal Plant. Journal of Applied Horticulture, 10: 164-168. 